\title{
TRANSFORMASI FUNGSI RUANG TERBUKA PUBLIK DI PERKOTAAN STUDI KASUS: TAMAN PEDESTRIAN KECAMATAN TENGGARONG, KABUPATEN KUTAI KARTANEGARA, KALIMANTAN TIMUR
}

\author{
Yulia Pratiwi \\ Jurusan Arsitektur Universitas Islam Indonesia \\ Kampus Terpadu UII Jl. Kaliurang KM 14,5, Sleman, Yogyakarta, 55584 \\ yulia_twins89@yahoo.co.id
}

\begin{abstract}
ABSTRAK. Ruang terbuka publik semakin dibutuhkan terutama bagi penduduk perkotaan untuk saling berinteraksi sosial. Pembangunan kota seringkali mengabaikan kebutuhan ruang terbuka bagi masyarakat umum untuk wadah saling berinteraksi dan bersosialisasi. Jenis-Jenis ruang terbuka publik yang semakin banyak dibangun di daerah-daerah di Indonesia adalah pedestrian dan taman kota. Fungsi ruang terbuka publik yang berupa pedestrian tersebut dari waktu ke waktu mengalami transformasi, tidak hanya sebagai jalur untuk berjalan dan ruang berinteraksi sosial maupun mewadahi aktivitas ekonomi, tetapi fungsi pedestrian mulai bertransformasi untuk mengangkat daya tarik kawasan sekitarnya. Metode yang digunakan adalah metode studi kasus tunggal holistik dengan pendekatan kualitatif untuk mengetahui apa fungsi-fungsi taman pedestrian di Kecamatan Tenggarong, Kabupaten Kutai Kartanegara, Kalimantan Timur. Hasil penelitian menunjukkan taman pedestrian di Kecamatan Tenggarong-Kutai Kartanegara memiliki fungsi sebagai (1) ruang interaksi sosial; (2) wadah aktifitas ekonomi; dan (3) ruang publik yang bertransformasi untuk menghidupkan kembali kawasan yang tidak produktif di sekitar jalur tersebut yaitu mengangkat daya tarik Pulau Kumala. Transformasi fungsi taman pedestrian di Tenggarong tersebut disebabkan karena faktor keberadaan obyek di kawasan sekitar dan kebijakan pembangunan.
\end{abstract}

Kata kunci: ruang terbuka publik, pedestrian, transformasi, Kecamatan Tenggarong

ABSTRACT. Public open space is increasingly needed, particularly for urban residents for social interaction. Urban development often ignores the needs of open space for the public to interact and socialize. Types of public open space which is increasingly built in the regions in Indonesia are pedestrian and the city park. The function of public open space in the form of the pedestrian from time to time through a transformation, not only as paths for walking and social interaction space as well as to facilitate economic activities, but the function of pedestrian started to transform to increase attractiveness of the surrounding area. The method that has been used is holistic-single case study with a qualitative approach to find out what functions pedestrian park in District Tenggarong, Kutai Kartanegara, East Kalimantan. The results showed pedestrian park in the district of Tenggarong has function as (1) social interaction space; (2) space for economic activities; and (3) public spaces are transformed to revive the unproductive areas around the track is raised the attractiveness of Kumala Island. Transformation functions of pedestrian park in Tenggarong was caused due to the presence of objects in the surrounding area and development policies.

Keywords: public open space, pedestrian, transformation, Tenggarong District

\section{PENDAHULUAN}

Dewasa ini, kota semakin mengalami perkembangan terutama perkembangan pada aktivitas perkotaan seperti aktivitas ekonomi perkotaan. Seiring dengan perkembangan aktivitas kota, Pemerintah baik tingkat kota/ kabupaten, provinsi dan pusat semakin gencar melakukan pembangunan kota untuk mengimbangi aktivitas kota. Namun, pembangunan kota seringkali mengabaikan kebutuhan ruang terbuka bagi masyarakat umum untuk wadah saling berinteraksi dan bersosialisasi. Salah satu alternatif untuk memenuhi kebutuhan ruang terbuka publik perkotaan adalah dengan melakukan pengoptimalan jalan dengan dibangun pedestrian atau city walk. Adanya pedestrian, maka kebutuhan ruang bagi pejalan kaki dapat terpenuhi dan dapat berperan sebagai ruang berinteraksi sosial dan sebagai ruang beraktivitas ekonomi.

Seiring pesatnya pembangunan dan kompleksnya aktivitas dan masalah perkotaan, pembangunan ruang terbuka publik mengalami perubahan atau transformasi fungsi. Ruang terbuka publik khususnya pedestrian yang awalnya diperuntukkan bagi pejalan kaki, kini mengalami transformasi fungsi yaitu sebagai trigger atau pemicu dan menghidupkan 
aktivitas yang ada serta mengangkat daya tarik di kawasan pedestrian maupun sekitar.

Tujuan penelitian ini adalah untuk mengkaji fungsi ruang terbuka publik yang berupa taman pedestrian di Kecamatan Tenggarong, Kabupaten Kutai Kartanegara, Provinsi Kalimantan Timur. Penelitian ini mengkaji fasilitas taman pedestrian, dan bentuk-bentuk aktivitas yang ada. Dengan mengetahui bentuk-bentuk aktivitas maka dapat digunakan untuk menjawab tujuan penelitian ini yaitu untuk mengetahui apa fungsi pedestrian dalam hal kegunaan ruang untuk publik yang berfungsi sebagai ruang interaksi sosial, aktivitas ekonomi ataupun untuk fungsi yang lain. Selain itu, tujuan penelitian ini juga untuk mengetahui "bagaimana" transformasi ruang terbuka publik pada taman pedestrian dan "mengapa" atau faktor-faktor apa saja yang mempengaruhi transformasi taman pedestrian di Kecamatan Tenggarong, Kabupaten Kutai Kartanegara, Kalimantan Timur.

\section{KAJIAN PUSTAKA}

\section{Ruang dan Ruang Terbuka}

Ruang menurut Undang-Undang RI Nomor 26 Tahun 2007 adalah wadah yang meliputi ruang darat, ruang laut, dan ruang udara, termasuk ruang di dalam bumi sebagai satu kesatuan wilayah, tempat manusia dan makhluk hidup, melakukan kegiatan, dan memelihara kelangsungan hidupnya. Ruang terbuka menurut Shirvani merupakan semua tentang landscape dan hardspace termasuk di dalamnya jalan, tempat berjalan, taman dan lainnya di daerah perkotaan [1]. Ruang terbuka sebagai elemen untuk membentuk kota. Elemen pembentuknya seperti ruang parkir, ruang pejalan kaki dan ruang terbuka hijau (pepohonan, tempat duduk, lampu, paving, kios-kios, bak sampah). Shirvani mengemukakan bahwa pedestrian bagian dari ruang publik dan menjadi aspek penting dalam sebuah urban space, baik berupa square (lapangan-ruang terbuka) maupun street (jalan-koridor). Shirvani menyatakan lapangan terbuka terbentuk karena gedung atau suatu area yang didesain memamerkan keindahan bangunan/ di sekitarnya [1]. Jalan menurut Kostof adalah satu kesatuan yang terdiri dari trotoar atau jalur pejalan kaki yang merupakan lingkupan bangunan sekitarnya [2]. Trotoar harus dapat meningkatkan lingkungan baik meningkatnya kegiatan manusia, kegiatan ekonomi masyarakat dan memperbaiki kualitas udara sekitar.

\section{Ruang Publik}

Ruang publik memiliki manfaat dan keuntungan dalam meningkatkan ekonomi, mendatangkan keuntungan bagi kesehatan manusia, sarana bersosialisasi, menjaga lingkungan [3]. Ruang publik menurut Kostof yaitu tempat aktivitas komunal dan tempat melakukan pertemuan dengan saudara, teman dan sebagainya di tempat umum [2]. Di ruang publik, setiap orang dapat melakukan kebebasan dalam melakukan kegiatan. Selain itu, terdapat pendapat lain mengenai ruang publik. Ruang publik juga dapat diartikan sebagai suatu tempat yang dapat mendatangkan keuntungan ekonomi serta sebagai tempat berkumpul masyarakat untuk mengekspresikan solidaritas dan tempat mengemukakan pendapat [4].

\section{Ruang Terbuka Publik}

Ruang terbuka publik mempunyai fungsi sebagai simpul dan sarana komunikatif serta sebagai pengikat sosial untuk menciptakan interaksi antara kelompok masyarakat dan sebagai tempat berkumpul sehari-hari dan pada kesempatan khusus [5].

\section{Interaksi Sosial}

Interaksi sosial adalah hubungan sosial yang dinamis antara orang satu dengan orang lain, kelompok-kelompok manusia, dan antara orang dengan kelompok masyarakat. Interaksi terjadi apabila dua orang atau kelompok saling bertemu dan terjadi komunikasi (yang berwujud pembicaraan, gerak badaniah atau sikap) antara kedua belah pihak [6]. Charles $P$. Loomis dalam Taneko menyatakan bahwa ciri penting dari interaksi sosial adalah (a) jumlah pelaku lebih dari satu orang, (b) adanya komunikasi antar pelaku dengan menggunakan simbol-simbol, (c) adanya tujuan tertentu, (d) adanya satuan dimensi waktu yang meliputi masa lampau, kini dan yang akan datang yang menentukan dari aksi yang sedang berlangsung [7].

\section{Transformasi}

Transformasi menurut Kamus Besar Bahasa Indonesia yaitu perubahan rupa (bentuk, sifat, fungsi, dan sebagainya).

\section{METODE PENELITIAN}

Metode yang digunakan adalah metode studi kasus. Kajian dalam penelitian ini menggunakan metode studi kasus tunggalholistik dengan pendekatan kualitatif. Alasan menggunakan metode studi kasus tunggalholistik atau menyeluruh dalam penelitian ini karena penelitian ini mempelajari dan 
menganalisis sebanyak mungkin data mengenai subjek yang diteliti dengan satu kasus amatan, merujuk pada fenomena yang kontemporer dalam konteks kehidupan nyata sehingga selain untuk menjawab "apa" fungsi ruang terbuka publik, juga muncul pertanyaan yang ingin dijawab pada penelitian ini yaitu "bagaimana" transformasi ruang terbuka publik pada taman pedestrian di Kecamatan Tenggarong, Kabupaten Kutai Kartanegara, Kalimantan Timur dan "mengapa" atau faktorfaktor apa saja yang mempengaruhi transformasi taman pedestrian yang ada di Kecamatan Tenggarong, Kabupaten Kutai Kartanegara, Provinsi Kalimantan Timur.

Pengumpulan data dilakukan dengan survey primer melalui observasi dan dokumentasi di lapangan terkait jenis aktivitas pengunjung, bentuk-bentuk aktivitas yang ada di taman pedestrian Tenggarong. Acuan yang diteliti menggunakan proposisi. Proposisi dibangun dari teori yang kemudian dijadikan acuan untuk dilakukan survey primer. Proposisi yang digunakan dalam penelitian ini dapat dilihat pada Gambar 1.

Lokasi penelitian yang dipilih pada penelitian ini adalah ruang terbuka publik yang berupa taman pedestrian di sepanjang jalan arteri Kecamatan Tenggarong yang terletak di sebelah Sungai Mahakam, Kabupaten Kutai Kartanegara, Kalimantan Timur. Lokasi penelitian dikhususkan pada taman pedestrian yang terletak di Jalan K.H Ahmad Muksin (Segmen 1) hingga Jalan Wolter Monginsidi (Segmen 2) dengan total panjang taman pedestrian yang menjadi fokus penelitian \pm 3 $\mathrm{km}$. Gambaran lokasi penelitian dapat dilihat pada Gambar 2.

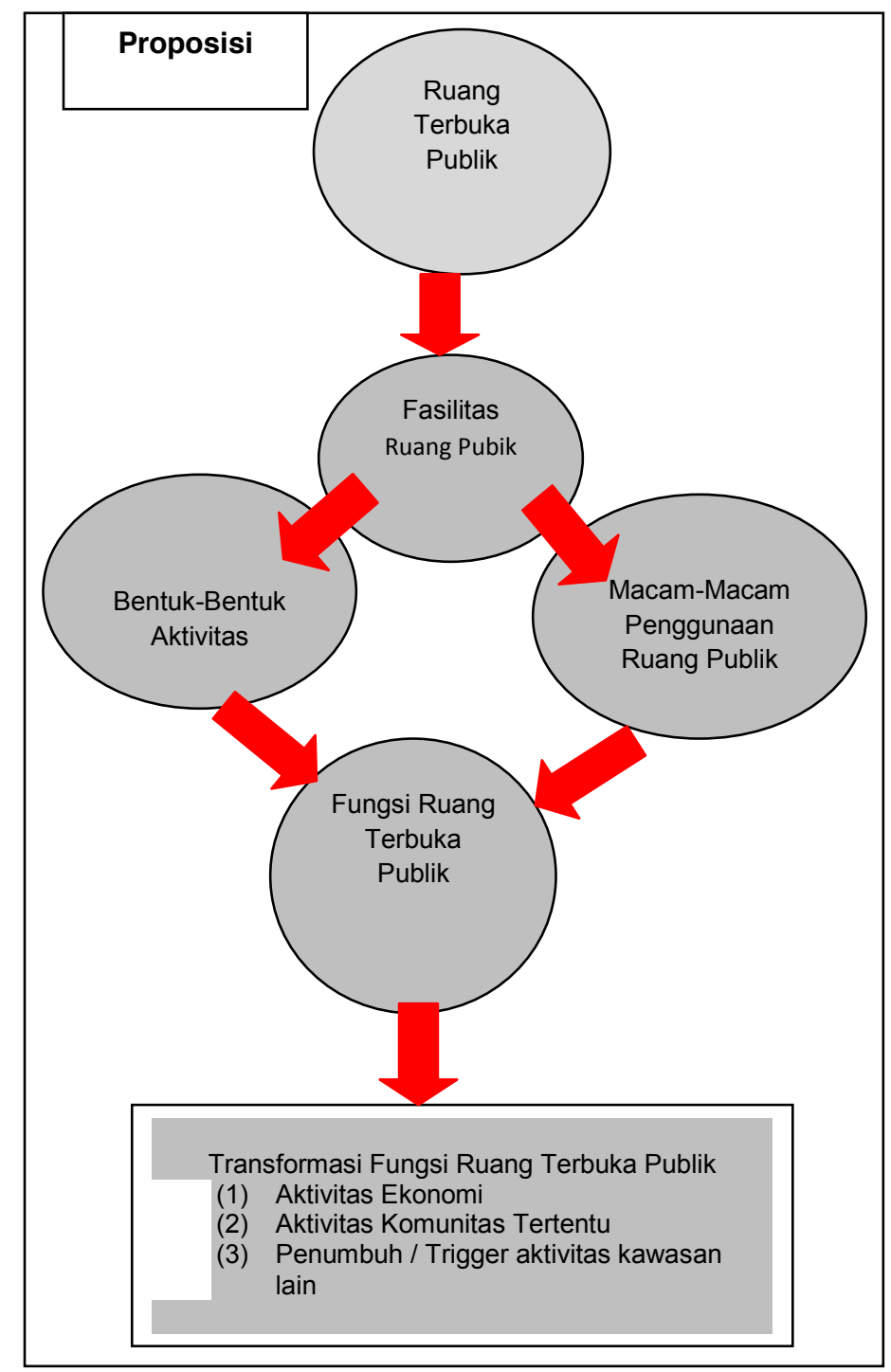

Gambar 1. Proposisi Penelitian Sumber: Penulis, 2015 


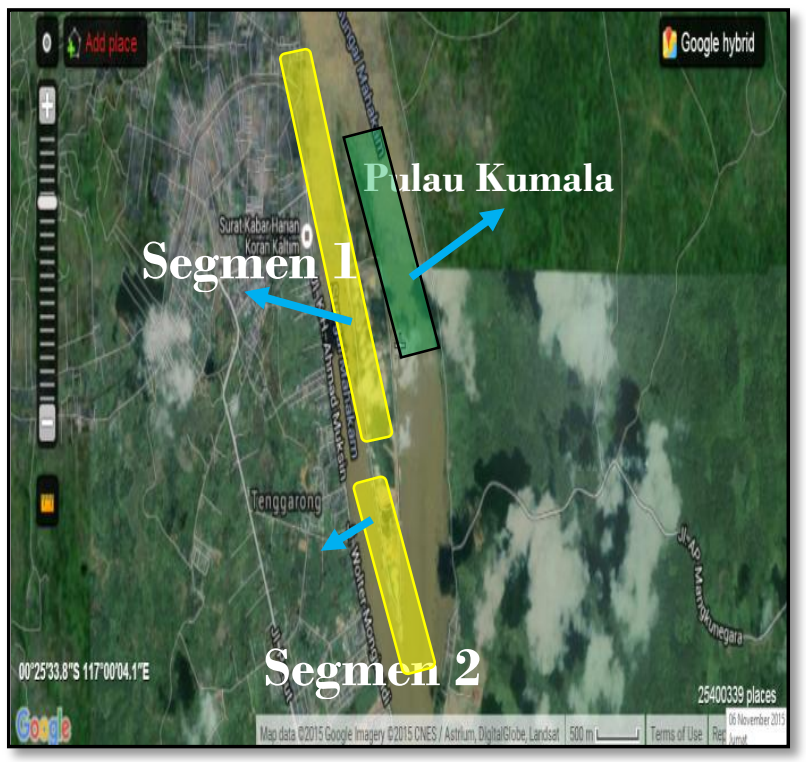

Gambar 2. Peta Lokasi Penelitian (Taman Pedestrian Tenggarong-Kutai Kartanegara Sumber: http://wikimapia.org

\section{HASIL DAN PEMBAHASAN}

\section{TAMAN PEDESTRIAN-SEGMEN 1}

\section{Batasan Lokasi Segmen 1}

Batasan Segmen I yaitu sepanjang Jalan K.H Ahmad Muksin. Batasan lokasi Segmen 1 ini ditentukan berdasarkan data awal yang berasal dari grandtour bahwa terdapat aktivitas di kasus Segmen 1 sehingga bisa diketahui transformasi fungsi ruang.

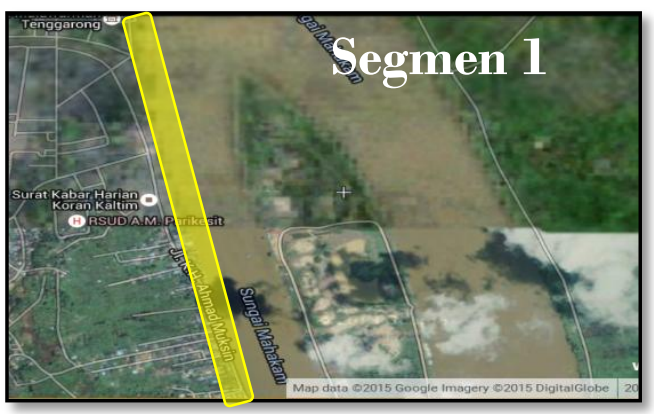

Gambar 3. Peta Lokasi Segmen 1 Sumber: http://wikimapia.org

\section{Fasilitas-Fasilitas di Segmen 1}

Taman Pedestrian di Jalan Ahmad Muksin (Segmen 1) tepatnya yang mengikuti pulau Kumala, terdapat fasilitas-fasilitas yang aksesibel digunakan oleh semua kalangan yaitu anak-anak, dewasa, orang tua dan orang berkebutuhan khusus atau difabel. Taman pedestrian di Segmen 1 ini dibangun pada tahun 2014 dengan penamaan sebagai Taman Kreatif. Fasilitas-fasilitas yang ada pada taman pedestrian Segmen 1 yaitu tempat sampah, area foto, panggung, Playground Area. Fasilitas-fasilitas yang ada di Segmen 1 dapat dijelaskan sebagai berikut:

a) Tempat sampah

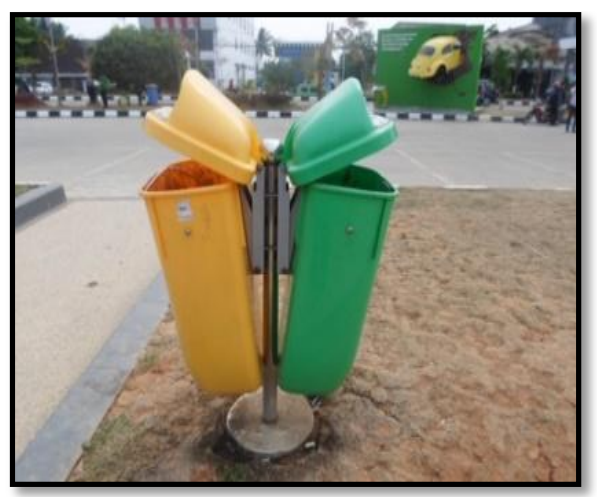

Gambar 4. Tempat sampah Sumber: Dokumentasi Penulis, 2015

b) Area Foto

Area foto berupa landmark yang merupakan landmark kata "Tenggarong". Dengan adanya landmark ini maka menjadi daya tarik pengunjung. 


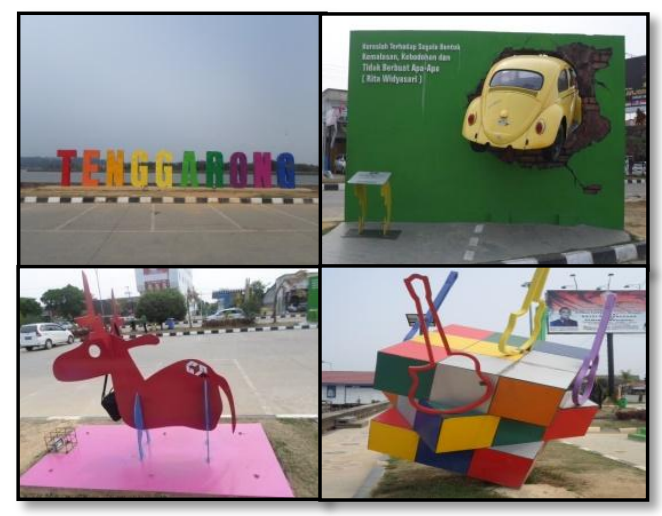

Gambar 5. Titik-Titik untuk Foto (landmark) Sumber: Dokumentasi Penulis, 2015

c) Panggung

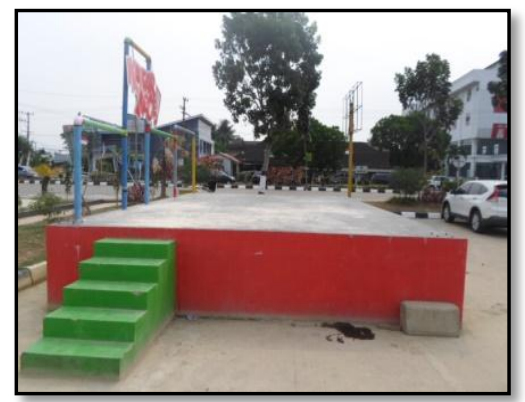

Gambar 6. Panggung

Sumber: Dokumentasi Penulis, 2015

d) Playground Area

Playground Area dikhususkan bagi anak kecil bermain dimana setiap sore hari mulai ramai dikunjungi.

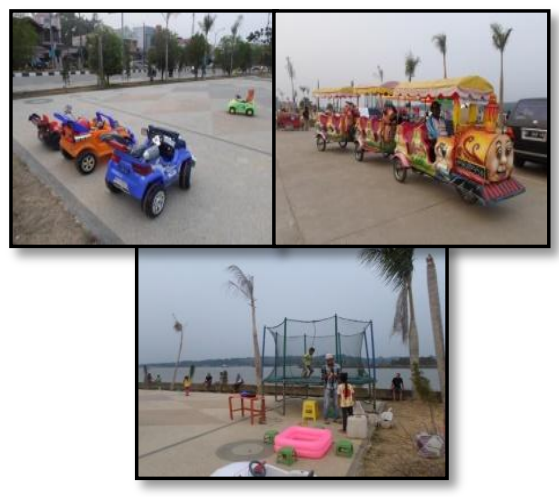

Gambar 7. Playground Area

Sumber: Dokumentasi Penulis, 2015

\section{Bentuk-Bentuk Aktivitas Segmen 1}

Dari beragam daya tarik dan fasilitas yang ditawarkan, maka bentuk-bentuk aktivitas di taman pedestrian Segmen 1 yaitu aktivitas bersantai, rekreasi, bermain, berjualan, dan berjalan. Aktivitas di taman pedestrian di
Tenggarong dapat dijabarkan sebagai berikut:

a) Aktivitas Bersantai

Aktivitas ini meliputi kegiatan mengobrol antara pengunjung satu dengan pengunjung lain; menikmati suasana dan pemandangan di taman pedestrian Tenggarong-Kutai Kartanegara dan keindahan Sungai Mahakam serta Pulau Kumala.
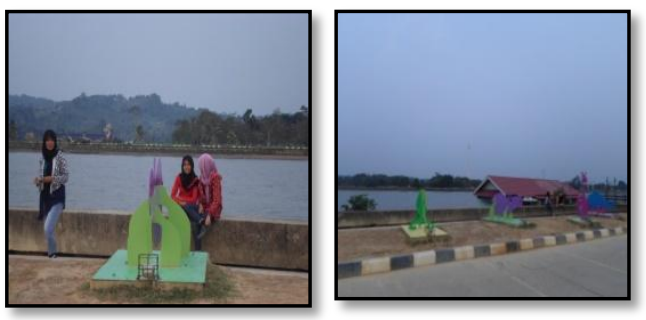

Gambar 8. Interaksi Sosial-Bersantai Sumber: Dokumentasi Penulis, 2015

b) Aktivitas Rekreasi

Aktivitas ini meliputi kegiatan memfoto, kegiatan mencari hiburan di taman pedestrian Tenggarong-Kutai Kartanegara.

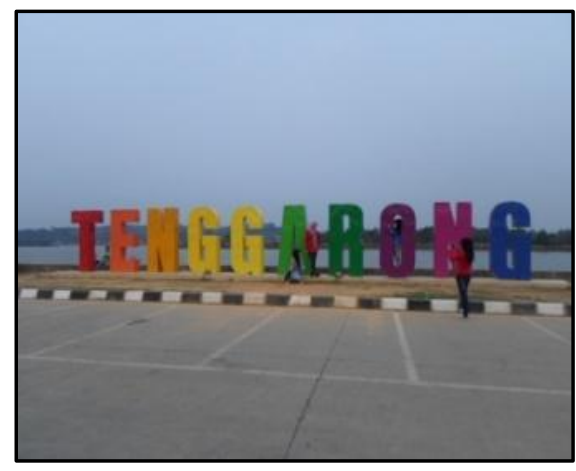

Gambar 9. Panggung

Sumber: Dokumentasi Penulis, 2015

c) Aktivitas Bermain

Aktivitas ini meliputi kegiatan menikmati fasilitas permainan yang ada di taman pedestrian. Umumnya dilakukan anakanak karena terdapat fasilitas penyewaan mobil mainan, kereta dan lain sebagainya.

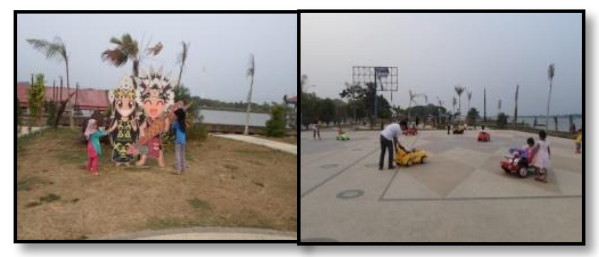

Gambar 10. Aktivitas Bermain Sumber: Dokumentasi Penulis, 2015 
d) Aktivitas Berjualan dan Jasa

Aktivitas ini meliputi kegiatan berdagang yang ada di taman pedestrian Tenggarong-Kutai Kartanegara.

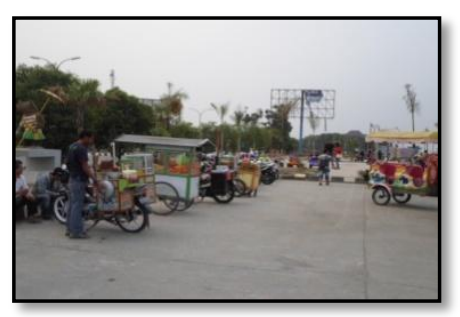

Gambar 11. Aktivitas Berjualan Sumber: Dokumentasi Penulis, 2015

e) Aktivitas berjalan

Di taman ini, banyak pengunjung datang untuk berjalan dengan menuju lokasi/ tempat lain.

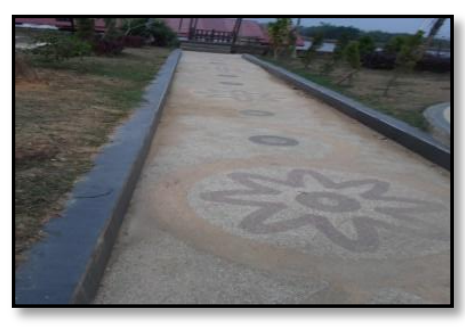

Gambar 12. Fasilitas Pejalan Kaki Sumber: Dokumentasi Penulis, 2015

4. Macam dan Fungsi Taman Pedestrian Segmen 1

Dari hasil analisis bentuk-bentuk aktivitas di Segmen 1, maka dapat diketahui bahwa macam dan fungsi taman pedestrian pada Segmen 1 yaitu sebagai berikut:

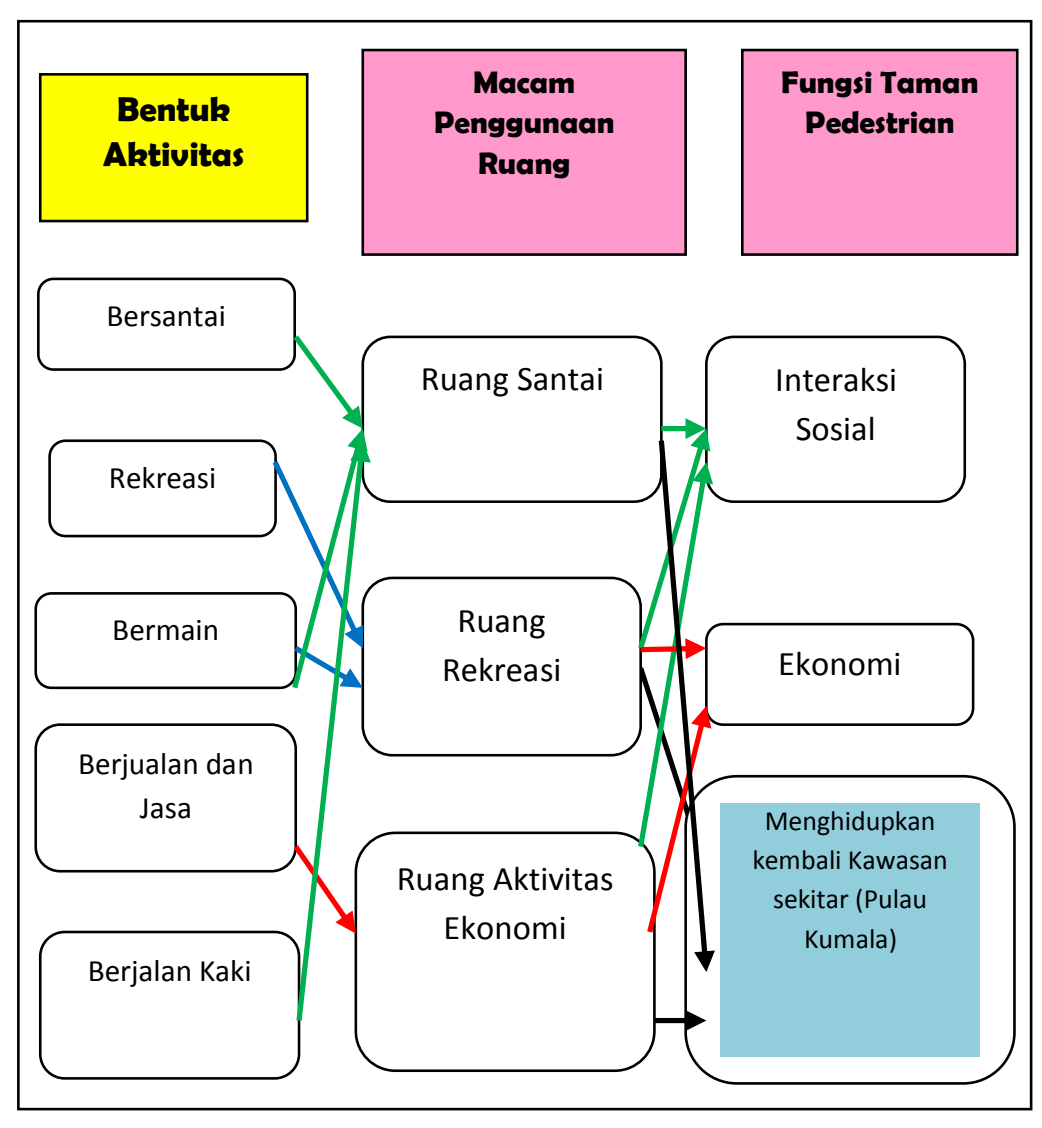

Gambar 13. Pemetaan Macam dan Fungsi Taman Pedestrian Sumber: Analisis Penulis, 2015 
TAMAN PEDESTRIAN-SEGMEN 2

1. Batasan Lokasi Segmen 2

Batasan Lokasi penelitian Segmen 2 yaitu pedestrian sepanjang Jalan Wolter Monginsidi.

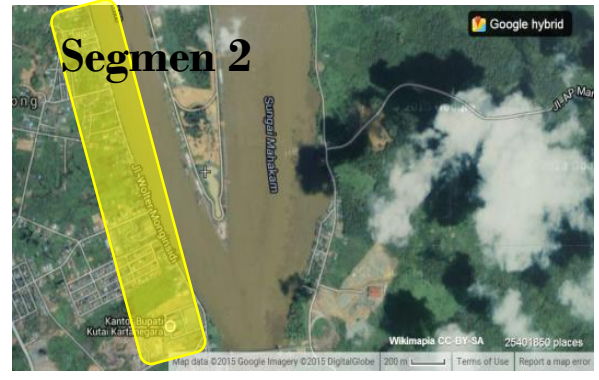

Gambar 14. Segmen 2

Sumber: Dokumentasi Penulis, 2015

\section{Fasilitas-Fasilitas Segmen 2}

Di segmen 2 yaitu pedestrian di Jalan Wolter Monginsidi tidak ada fasilitas khusus. Namun, di pedestrian Segmen 2 ini, terdapat titik atau spot unik yang berupa landmark yang mencerminkan kekhasan dan karakter Tenggarong. Landmark/ tetenger tersebut yaitu Patung Lembuswana. Berikut patung Lembuswana yang menjadi ikon Tenggarong.

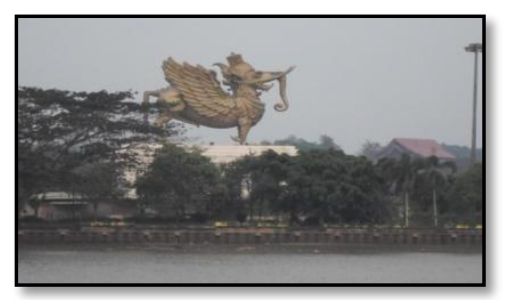

Gambar 15. Landmark "Lembuswana" Sumber: Dokumentasi Penulis, 2015

\section{Bentuk-Bentuk Aktivitas Pedestiran}

\section{Segmen 2}

Pada Pedestrian Segmen 2 ini, bentukbentuk aktivitas tidak sebanyak di Segmen 1 karena fasilitas yang ada di Segmen 2 memang dikhususkan bagi pejalan kaki. Bentuk aktivitas pedestrian di Segmen 2 dapat dijabarkan sebagai berikut ini: a) Aktivitas Bersantai

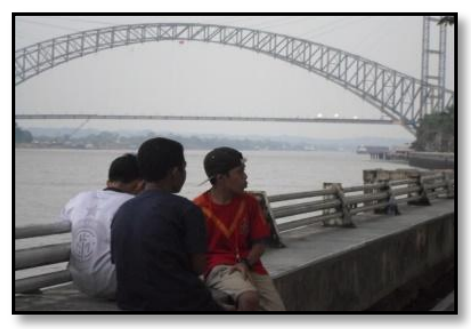

Gambar 16. Bersantai di Pedestrian Sumber: Dokumentasi Penulis, 2015

b) Aktivitas Berjalan

Pedestrian pada Segmen 2 ini memang diperuntukkan sebagai pejalan kaki dengan fasilitas jalannya adalah sebagai berikut:

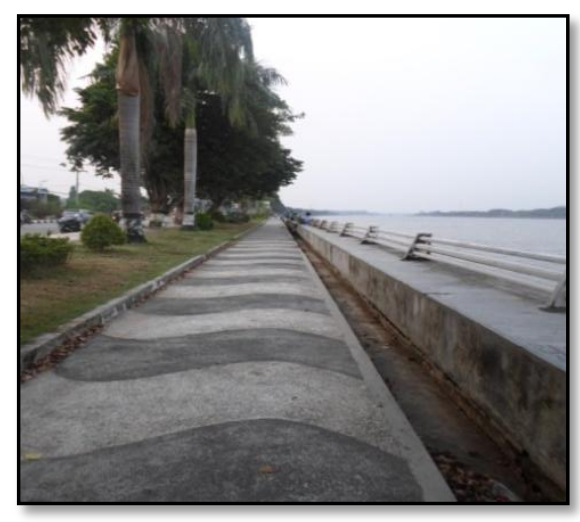

Gambar 17. Jalan Pedestrian Sumber: Dokumentasi Penulis, 2015

\section{Macam dan Fungsi Taman Pedestrian} Segmen 2

Dari hasil analisis bentuk-bentuk aktivitas di Segmen 2, maka dapat diketahui bahwa macam dan fungsi taman pedestrian pada Segmen 2 yaitu sebagai berikut: 


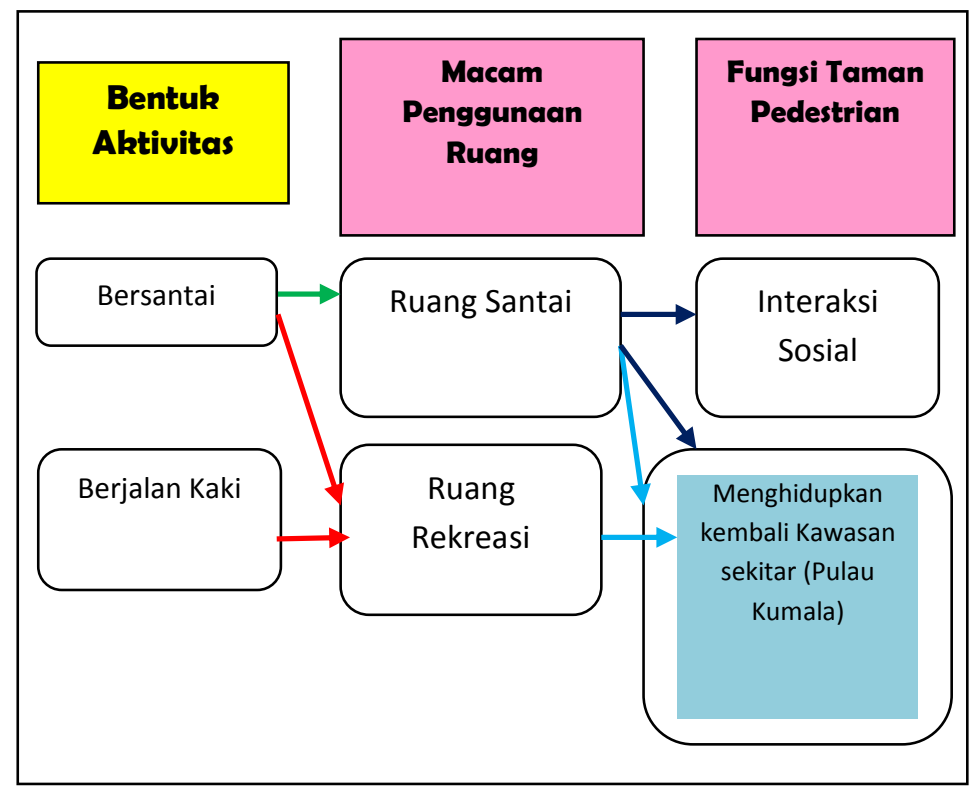

Gambar 18. Macam dan Fungsi Pedestrian Segmen 2 Sumber: Analisis penulis, 2015

\section{Analisis Hubungan Pedestrian dan Obyek yang berada di Sekitar Lokasi Penelitian}

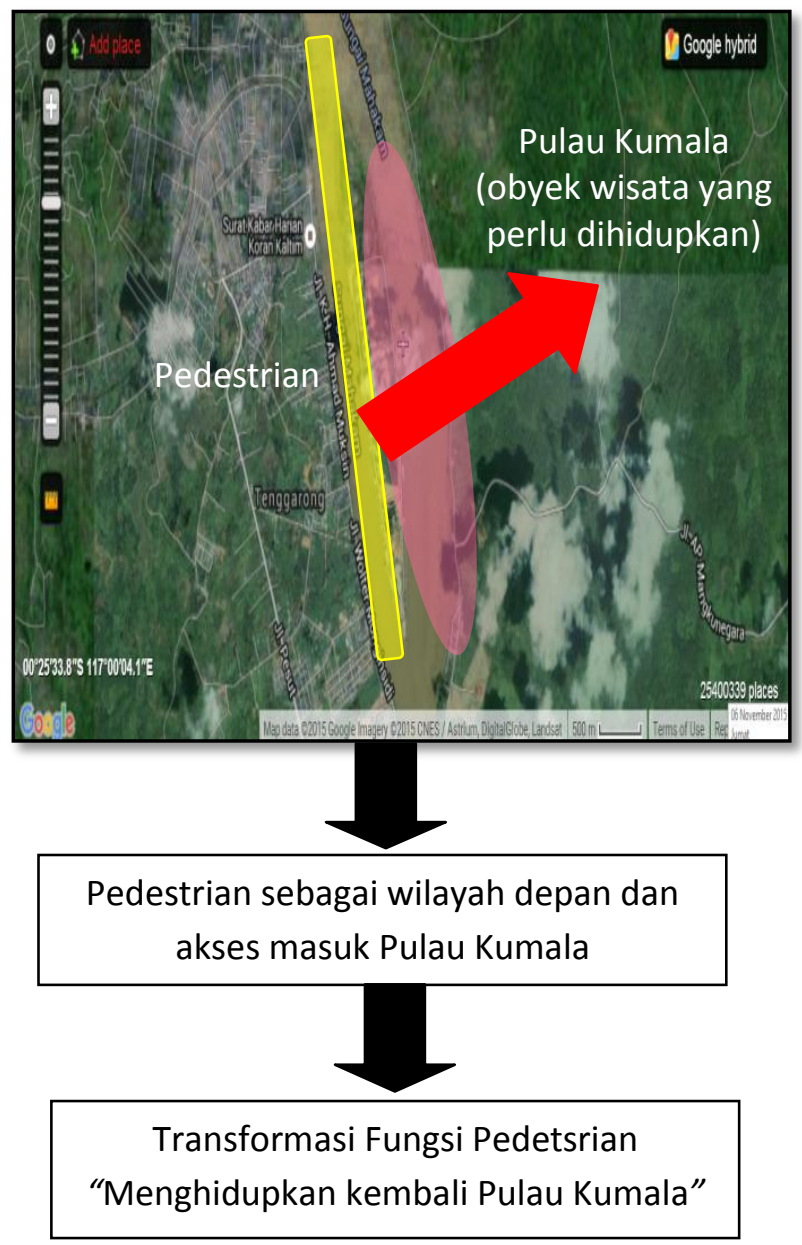

\section{Pembahasan Transformasi Pedestrian Tenggarong-Kutai Kartanegara}

Dari data dan analisis yang sudah dilakukan di atas, maka dapat diketahui bahwa terjadi transformasi atau perubahan fungsi pedestrian. Pedestrian tidak hanya berfungsi sebagai ruang interaksi sosial, dan mewadahi aktivitas ekonomi saja, tetapi juga berfungsi sebagai trigger atau pemicu untuk menghidupkan kembali kawasan yang tidak produktif di sekitar jalur tersebut yaitu mengangkat daya tarik Pulau Kumala.

\section{Fungsi Pedestrian untuk Menghidupkan Kembali Pulau Kumala}

Pulau Kumala merupakan daerah delta Sungai Mahakam yang berada di Tenggarong-Kutai Kartanegara. Pada tahun 2000, Pulau Kumala resmi dijadikan obyek wisata dengan wahana yang bermacammacam yang ada di Tenggarong-Kutai Kartanegara. Pulau Kumala memiliki cerita mistis yang menjadikan Pulau ini tidak cukup diminati pengunjung. Pulau Kumala memiliki luas area sebesar \pm 81 ha dan terdapat sky tower setinggi 100 meter dan kereta gantung yang menghubungkan dengan wilayah seberang sungai Mahakam. Selain itu, di Pulau Kumala sudah dilengkapi dengan fasilitas hotel dan penginapan. Namun fasilitas-fasilitas yang ada di Pulau Kumala masih belum menjadi daya tarik dan jumlah pengunjung masih minim. Untuk meningkatkan daya tarik Pulau Kumala tersebut, maka Pemerintah Kabupaten Kutai Kartanegara membangun 
pedestrian untuk menyediakan ruang interaksi sosial dan peningkatan ekonomi serta dapat sekaligus menunjang daya tarik dan menghidupkan kembali Pulau Kumala.

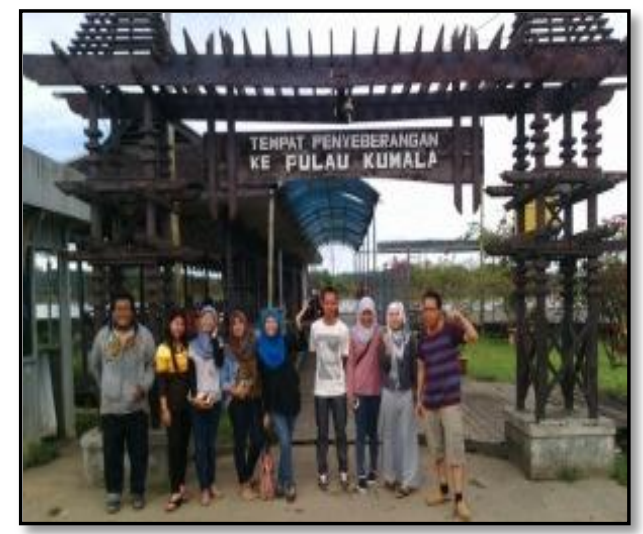

Gambar 19. Akses masuk Pulau Kumala Sumber:

https://jefrihutagalung.wordpress.com

7. Faktor-faktor yang mempengaruhi Fungsi Pedestrian Tenggarong-Kutai Kartanegara

Transformasi fungsi pedestrian di Tenggarong dimana tidak hanya sebagai ruang interaksi sosial dan ekonomi, tetapi juga sebagai trigger atau pendorong daya tarik dan menghidupkan kembali kawasan wisata Pulau Kumala. Hal itu disebabkan karena faktor keberadaan obyek di kawasan sekitar yang memang tidak produktif sehingga memunculkan ide bagi Pemerintah Daerah, Kutai Kartanegara untuk membuat kebijakan pembangunan pedestrian dan taman di delta Sungai Mahakam.

\section{KESIMPULAN}

Kesimpulan dari penelitian ini adalah fungsi pedestrian di Jalan K.H. Ahmad Muksin dan Jalan Wolter Monginsidi, Kecamatan Tenggarong, Kabupaten Kutai Kartanegara, Kalimantan Timur mengalami transformasi. Pedestrian di Jalan K.H. Ahmad Muksin dan Jalan Wolter Monginsidi, Kecamatan Tenggarong, Kabupaten Kutai Kartanegara, Kalimantan Timur tidak hanya berfungsi sebagai (1) ruang interaksi sosial dan (2) aktivitas ekonomi, tetapi juga (3) menghidupkan kembali Pulau Kumala yang sebelumnya tidak produktif. Macam kegunaan ruang di pedestrian Tenggarong adalah ruang ruang bersantai, ruang rekreasi dan ruang aktivitas ekonomi. Pedestrian di Kecamatan Tenggarong, Kabupaten Kutai Kartanegara, Provinsi Kalimantan Timur mampu menjadi ruang terbuka publik yang dapat mewadahi kebutuhan warga untuk melakukan interaksi, kegiatan sosial maupun budaya sekaligus berfungsi menghidupkan kembali kawasan sekitar. Faktor-faktor yang mempengaruhi adanya transformasi fungsi ruang terbuka publik (pedestrian) di Jalan K.H Ahmad Muksin dan Jalan Wolter Monginsidi, Kecamatan Tenggarong, Kabupaten Kutai Kartanegara, Kalimantan Timur yaitu (1) faktor keberadaan obyek di kawasan sekitar, dan (2) kebijakan pembangunan.

\section{REFERENSI}

[1] Shirvani, Hamid. (1985). The Urban Design Process. Van Nostrand Reinhold Co. Newyork.

[2] Kostof, Spiro. (1991). The City Shaped : Urban Patterns and Meanings Through History. Little, Brown, and Company.

[3] Carmona, Matthew, Clauido de Magalhaes and Leo Hammond. (2008). Public Space: The Management Dimension. Routledge. London

[4] Shaftoe, Henry. (2008). Convivial Urban Spaces: Creating Effective Public Spaces. Earthscan. London.

[5] Haryanti, D.T. (2008). Kajian Pola Pemanfaatan Ruang Terbuka Publik Kawasan Bundaran Simpang Lima Semarang. Semarang.

[6] Yulianti, Yayuk. (2003). Sosiologi Pedesaan. Lappera Pustaka Utama. Yogyakarta.

[7] Taneko, Soleman B. (1984). Struktur dan Proses Sosial Suatu Pengantar. Rajawali. Jakarta.

[8] https://jefrihutagalung.wordpress.com (diakses pada Tanggal 01 November 2015 pukul 08.15 WIB)

[9] Kamus Besar Bahasa Indonesia

[10] Kementerian PU. Undang-Undang No. 26 Tahun 2007 tentang Penataan Ruang 
